\title{
HOT CARRIERS IN TUNNEL DIODE
}

\author{
S. Ašmontas ${ }^{\mathrm{a}, \mathrm{b}}$, J. Gradauskas ${ }^{\mathrm{a}, \mathrm{c}}$, J. Paukštė $^{\mathrm{b}}$, V. Petkun ${ }^{\mathrm{a}}$, D. Seliuta ${ }^{\mathrm{a}}$, \\ A. Sužiedèlis ${ }^{\text {a,c }}$, E. Širmulis ${ }^{\text {a }}$, and G. Valušis ${ }^{\mathrm{a}, \mathrm{c}}$ \\ ${ }^{a}$ Semiconductor Physics Institute, A. Goštauto 11, LT-01108 Vilnius, Lithuania \\ ${ }^{\mathrm{b}}$ Kaunas University of Technology, Panevéžys Institute, Klaipèdos 3, LT-35209 Panevéžys, Lithuania \\ ${ }^{\mathrm{c}}$ Vilnius Gediminas Technical University, Saulètekio 11, LT-10223 Vilnius, Lithuania \\ E-mail: jonas@pfi.lt
}

Received 27 January 2004

\begin{abstract}
We present the first results of experimental study of free carrier heating in a degenerate semiconductor when the carriers were excited by $\mathrm{CO}_{2}$ laser light and microwave radiation of 10 and $35 \mathrm{GHz}$. Tunnel GaAs $p-n$ diodes were used as objects under investigation. It is shown that the carrier heating reduces the dark tunnel current, while at high enough forward bias the thermo-diffusive current is responsible for the formation of the signal. The magnitude of the electromotive force arising under the microwave irradiation depends linearly on the power and increases with the decrease of the semiconductor lattice temperature. It is nearly independ of the microwave frequency.
\end{abstract}

Keywords: hot carriers, degenerate semiconductor, tunnel diode, infrared radiation, microwaves

PACS: $07.57 . \mathrm{Kp}, 73.40 . \mathrm{Gk}, 78.70 . \mathrm{Gq}$

\section{Introduction}

Carrier heating by external electromagnetic radiation in moderately doped semiconductors has been widely investigated during last decades [1]. It is established that an electromotive force (emf) arises due to carrier heating in inhomogeneous semiconductors $[1,2]$. The hot carrier emf $U_{T}$ originates because of the change of mobility and diffusion coefficients under the influence of strong electric field. Investigations of the hot carrier emf show that the magnitude of $U_{T}$ is directly proportional to the potential barrier height of a $p-n$ junction $[1,3]$. Therefore, in order to increase the sensitivity of a sensor operating on the basis of carrier heating in the inhomogeneous structures, it is necessary to increase the carrier concentration in $n$ - and $p$-regions of the $p-n$ junction. But the increase of doping level leads to the degeneration of electron and hole gases. A semiconductor becomes degenerate when the carrier concentration exceeds critical value $N_{\mathrm{C}}$ determined as

$$
N_{\mathrm{C}}=\frac{2}{h^{3}}\left(2 \pi m^{*} k T_{0}\right)^{3 / 2},
$$

where $m^{*}$ is the electron effective mass, $h$ and $k$ are Planck's and Boltzmann constants, respectively, and $T_{0}$ represents the semiconductor lattice temperature. Thus, the degeneracy of the regions close to the abrupt $p-n$ junction leads to the carrier tunnelling, i. e. the nature of carrier flow across the junction changes substantially, namely, the injection current is replaced by the tunnel one.

Since the invention of the nonresonant tunnel $p-n$ diodes, especially of the backward ones, they are widely used to detect microwave radiation (see, for instance, [4]). However, their operation is mainly based on the rectification of high frequency currents due to the asymmetry of $I-V$ characteristic.

In this communication we investigate the ways of carrier flow across the tunnel $p-n$ junction when the carriers are heated by the microwave and infrared radiation.

\section{Samples and experimental technique}

The investigated tunnel diodes were fabricated on the base of epitaxial GaAs structures grown by molecular beam epitaxy on semiinsulating GaAs substrates. The thickness of $p^{+}$- and $n^{+}$-layers was 0.4 and $0.6 \mu \mathrm{m}$, respectively. High carrier densities $\left(p^{+}=\right.$ $5 \cdot 10^{19} \mathrm{~cm}^{-3}$ and $n^{+}=3 \cdot 10^{18} \mathrm{~cm}^{-3}$ ) as well as an abrupt doping profile were achieved using amphoteric nature of silicon on the (311) GaAs surface. The samples were etched as $120 \times 120 \mu \mathrm{m}^{2}$ mesas with evap- 


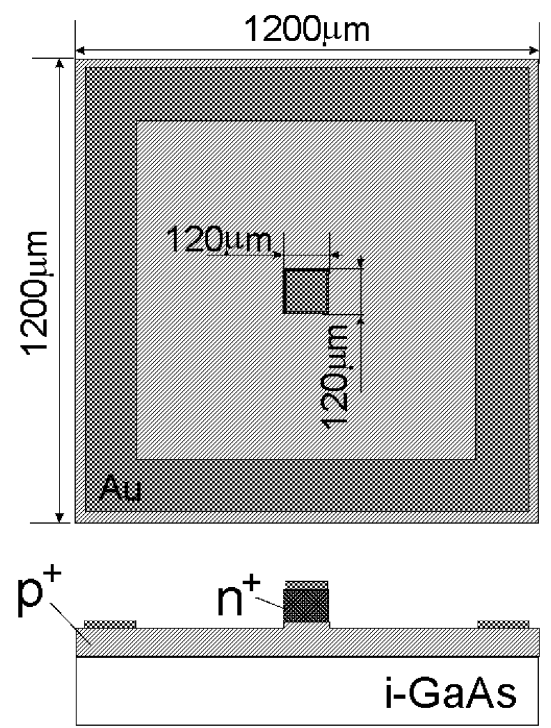

Fig. 1. Schematic view of the tunnel diode: $n^{+}=3 \cdot 10^{18} \mathrm{~cm}^{-3}$ and $p^{+}=5 \cdot 10^{19} \mathrm{~cm}^{-3} ; h_{n^{+}}=600 \mathrm{~nm}$ and $h_{p^{+}}=400 \mathrm{~nm}$ are thicknesses of the respective epitaxial layers.

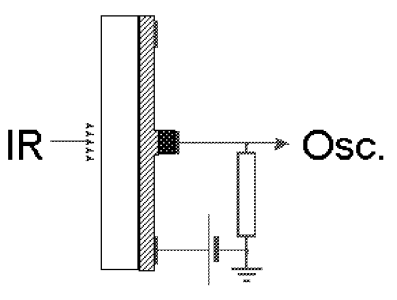

(a)

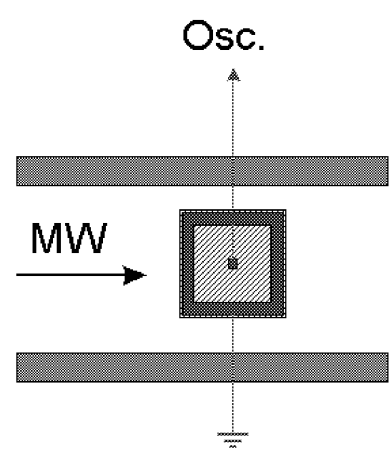

(b)
Fig. 2. Measurement schemes under (a) infrared and (b) microwave excitation.

orated and annealed $\mathrm{Ni}-\mathrm{Au}-\mathrm{Ge}$ metal contacts on the top (see Fig. 1).

Short pulses of infrared and microwave radiation were applied in order to avoid the crystal lattice heating. As a source of infrared radiation we used the Q-switched $\mathrm{CO}_{2}$ laser with $10.6 \mu \mathrm{m}$ wavelength, $200 \mathrm{~ns}$ pulse duration, and $40 \mathrm{~Hz}$ repetition rate. Maximum intensity was about $1.2 \mathrm{MW} / \mathrm{cm}^{2}$. The $p-n$ junction was illuminated from the substrate side. Figure 2(a) shows the measurement circuit.

In the case of microwave excitation the tunnel diode was placed inside the waveguide in such a way that the electric field was parallel with the $p-n$ junction plane (see Fig. 2(b)). Magnetrons generating microwave pulses of 10 and $1 \mathrm{~kW}$ power at 10 and $35 \mathrm{GHz}$ frequencies, respectively, were used as microwave radi-

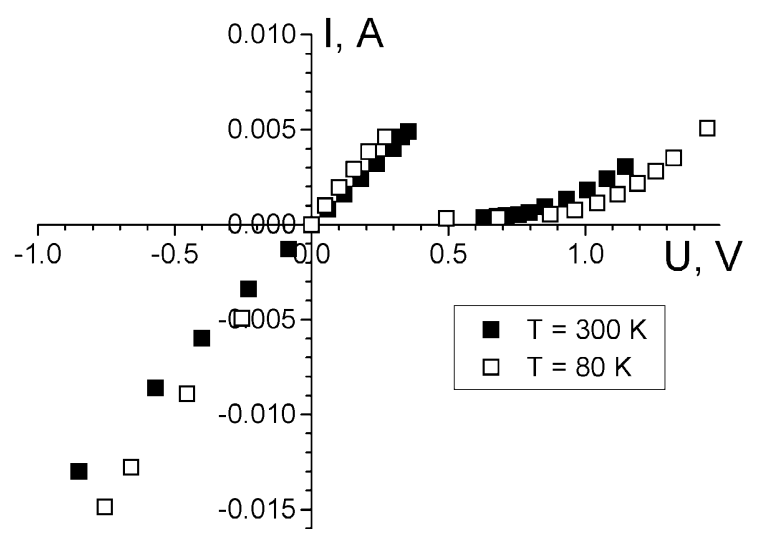

Fig. 3. Dark voltage-current characteristics of the tunnel diode at room and liquid nitrogen temperatures.

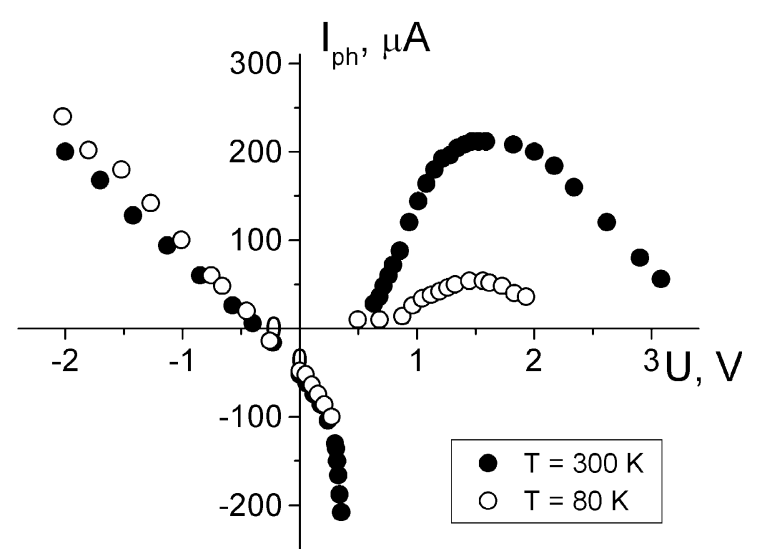

Fig. 4. The dependence of photocurrent on applied bias voltage at room and liquid nitrogen temperatures. The diode is illuminated with the $\mathrm{CO}_{2}$ laser light.

ation sources. The measurements were performed at room and liquid nitrogen temperatures.

\section{Experimental results and discussion}

Dark current-voltage characteristics of the tunnel $p-n$ junction measured both at room and at liquid nitrogen temperatures are presented in Fig. 3. It is worth noting that the tunnel current increases with the decrease of the lattice temperature. As known [5], the tunnel current across the junction can be expressed as

$$
I=A \frac{e U}{4 k T_{0}}\left(E_{C}-E_{V}\right)^{2},
$$

where $A$ is a constant, $U$ stands for bias voltage, $E_{C}$ and $E_{V}$ represent conduction and valence band edges, respectively. Comparison of the theory with the experimental measurements shows sufficient qualitative agreement. 


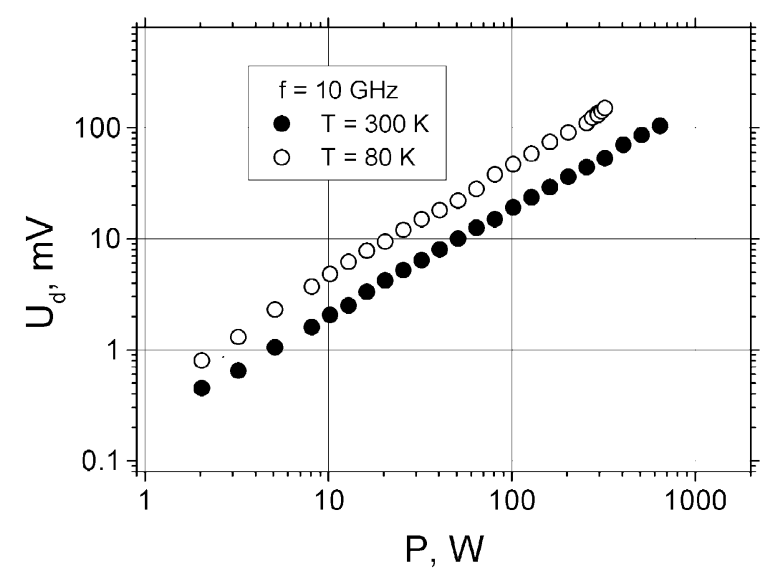

Fig. 5. The photosignal across the diode versus incident microwave power at room and liquid nitrogen temperatures. Microwave frequency is $10 \mathrm{GHz}$.

Illumination of the tunnel $p-n$ junction with the $\mathrm{CO}_{2}$ laser radiation causes the decrease of the dark tunnel current. The dependence of the photocurrent on bias voltage is depicted in Fig. 4. At reverse and low forward bias values the photocurrent monotonically changes with the bias voltage. At higher values of the forward bias the direction of the photocurrent abruptly changes. This indicates that at higher forward bias values the current across the diode increases under the illumination. Both the polarity of the photosignal and the typical maximum of the photocurrent suggest the hot carrier emission over the barrier to be responsible for the photocurrent formation at the higher forward bias, similarly as in a moderately doped $p-n$ junction [3].

The decrease of the tunnel current when the junction is exposed to the $\mathrm{CO}_{2}$ laser radiation can be explained by the free carrier heating. Let us assume that the degenerate electron and hole gases are heated by the laser radiation to the same temperature $T_{\mathrm{e}}$. Then the photocurrent can be expressed as

$$
I_{\mathrm{ph}}=A \frac{e\left[\left(U+U_{T}\right) T_{0}-U T_{\mathrm{e}}\right]}{4 k T_{\mathrm{e}} T_{0}}\left(E_{C}-E_{V}\right)^{2} .
$$

As seen, the photocurrent is directly proportional to the change of the carrier temperature in warm electron region, when $T_{\mathrm{e}}-T_{0} \ll T_{0}$.

Experimental study of the voltage $U_{\mathrm{d}}$ across the diode under the microwave radiation shows that $U_{\mathrm{d}}$ depends linearly on the microwave power in a wide intensity range (see Fig. 5). This is a characteristic feature of the emfs caused by free carrier heating [1]. The value of $U_{\mathrm{d}}$ at lower lattice temperature is higher than at room temperature. This fact can be explained by the higher

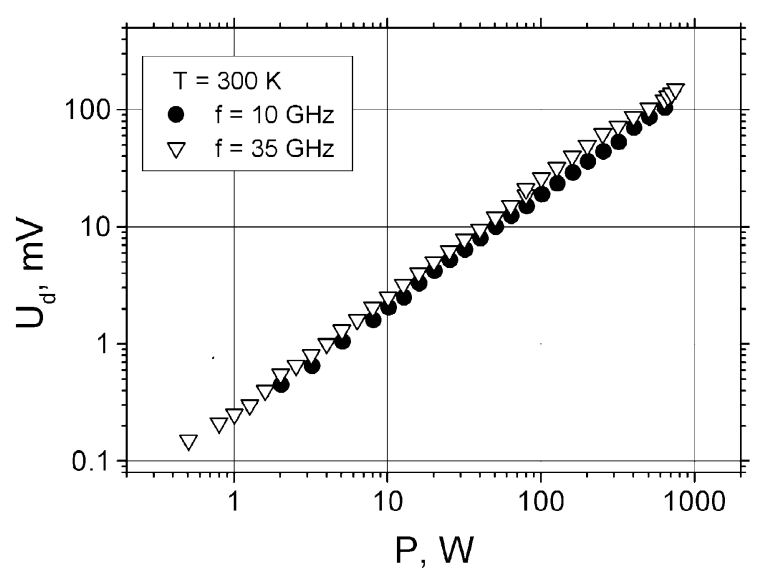

Fig. 6. The photosignal across the diode versus incident microwave power at 10 and $35 \mathrm{GHz}$ frequencies measured at room temperature.

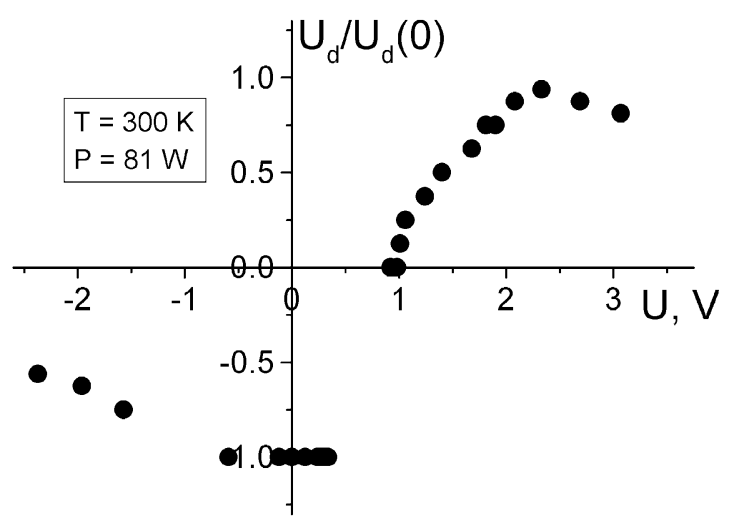

Fig. 7. The dependence of the photosignal (normalized to the zerobias value) on applied bias voltage at room temperature. The diode is illuminated with the microwaves of $10 \mathrm{GHz}$ frequency and $81 \mathrm{~W}$ incident power.

value of the difference $T_{\mathrm{e}}-T_{0}$ at $T_{0}=80 \mathrm{~K}$ compared to that at $T_{0}=300 \mathrm{~K}$. Since the value of carrier energy relaxation time increases with the decrease of the semiconductor lattice temperature [6], the value of $T_{\mathrm{e}}-T_{0}$ increases with decreasing $T_{0}$ at constant strength of the electric field.

The dependences of $U_{\mathrm{d}}$ on the power at two different microwave frequencies are shown in Fig. 6. Apparently, the magnitude of $U_{\mathrm{d}}$ is almost independent of the frequency. This fact indicates that the main contribution to the measured voltage is related to the carrier heating by the electric field of the radiation, just as it was observed in the investigations of the hot carrier thermoelectric force arising across the $n-n^{+}$junction [7].

It is worth to note that $U_{\mathrm{d}}$ strongly depends on the bias voltage applied to the diode (see Fig. 7). Several specific features of the dependence can be easily 
distinguished. First, the measured voltage monotonically varies with the bias voltage at reverse and low forward bias. Second, at higher values of the forward bias, $U_{\mathrm{d}}$ abruptly changes its polarity, what can be explained by the change of the nature of carrier flow across the $p-n$ junction. As already mentioned, in the case of the laser excitation at low values of forward bias the current flowing across the junction originates from the electron tunnelling through the barrier. Carrier heating causes the decrease of the magnitude of the tunnel current. As a result, the measured signal has negative polarity. When the forward bias is increased, the tunnel current diminishes, while the thermo-diffusive current rises. That is the reason why at forward bias the abrupt change of the $U_{\mathrm{d}}$ polarity takes place. Further increase of forward $U$ causes the measured signal to reach its maximum value, and then to start decreasing. Such behaviour of $U_{\mathrm{d}}$ on the bias voltage is characteristic of all types of $p-n$ junctions, when the carriers are heated by external radiation [7].

\section{Conclusions}

Free carrier heating was experimentally observed for the first time in a degenerate semiconductor at room and liquid nitrogen temperatures. Nanosecond pulses of infrared radiation and microsecond pulses of microwave radiation were used as excitation sources. The magnitude of the response of the tunnel diode weakly depends on the frequency of the microwave radiation.

\section{Acknowledgement}

The investigated samples were fabricated at the Braun Center for Submicron Research of the Weizmann Institute of Sciences with kind assistance of Prof. M. Heiblum and Dr. H. Shtrikman under the support of the European Commission within the Large Scale Facility Programme (contract No. HPRI-CT1999-00069).

\section{References}

[1] S. Ašmontas, J. Gradauskas, A. Sužiedèlis, E. Širmulis, and G. Valušis, Interaction of microwaves and infrared radiation with semiconductors: Study and applications, Lithuanian J. Phys. 40(1-3), 15-25 (2000).

[2] S. Ašmontas and A. Sužiedèlis, Hot electron thermoelectricity, J. Thermoelectricity 1, 5-26 (1997).

[3] S. Ašmontas, J. Gradauskas, D. Seliuta, A. Sužiedèlis, E. Širmulis, and G. Valušis, Application of hot-carrier thermo-electromotive force for measurement of pulsed microwave and infrared radiation, J. Thermoelectricity 4, 15-28 (1998).

[4] S.Y. Liao, Microwave Devices and Circuits, 3rd edn. (Prentice-Hall, New York, 1990).

[5] K. Seeger, Semiconductor Physics (Springer-Verlag, Wien, 1973).

[6] A. Dargys and J. Kundrotas, Handbook on Physical Properties of Ge, Si, GaAs and InP (Science and Encyclopedia, Vilnius, 1994).

[7] S. Ašmontas, Electrogradient Phenomena in Semiconductors (Mokslas, Vilnius, 1984).

\title{
KARŠTIEJI KRŪVININKAI TUNELINIAME DIODE
}

\author{
S. Ašmontas ${ }^{\text {a,b }}$, J. Gradauskas ${ }^{\text {a,c }}$, J. Paukšte $^{\text {b }}$, V. Petkun ${ }^{\text {a }}$, D. Seliuta ${ }^{\text {a }}$, \\ A. Sužiedèlis ${ }^{\text {a,c }}$, E. Širmulis ${ }^{\text {a }}$, G. Valušis ${ }^{\text {a,c }}$ \\ ${ }^{a}$ Puslaidininkiu fizikos institutas, Vilnius, Lietuva \\ b Kauno technologijos universitetas, Panevéžio institutas, Panevéžys, Lietuva \\ ${ }^{\mathrm{c}}$ Vilniaus Gedimino technikos universitetas, Vilnius, Lietuva
}

\begin{abstract}
Santrauka
Pateikti pirmi laisvụjų krūvininkų kaitimo eksperimentinių tyrimų rezultatai, krūvininkus sužadinant tiek $\mathrm{CO}_{2}$ lazerio spinduliuote, tiek ir 10 bei $35 \mathrm{GHz}$ dažnio mikrobagomis. Tyrimams buvo naudojami tuneliniai GaAs $p-n$ diodai. Parodyta, kad krūvininku kaitimas silpnina tamsinę tunelinę srovę, o esant pakanka-
\end{abstract}

mai didelei išorinei tiesioginei įtampai, matuojamajji signalą nulemia šiluminè-difuzinè srovè. Elektrovaros, atsirandančios paveikus diodą mikrobangomis, stiprumas yra tiesiogiai proporcingas spinduliuotès galiai ir didèja, žeminant puslaidininkio kristalinès gardelès temperatūrą, tuo tarpu jis beveik nepriklauso nuo mikrobangu dažnio. 